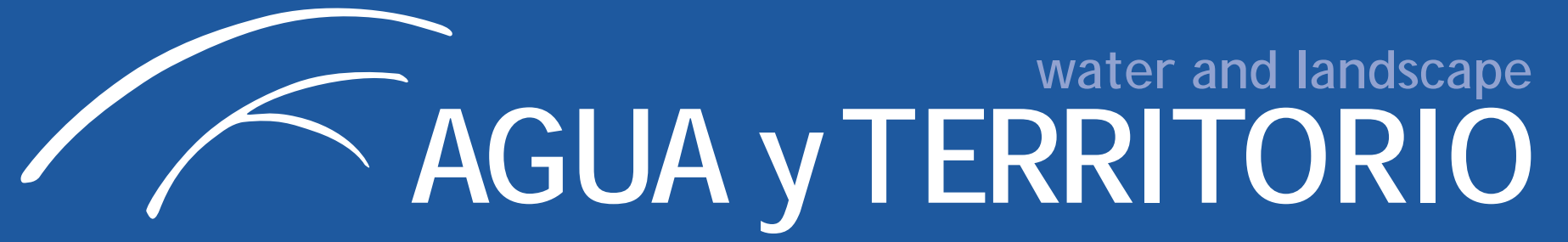

\title{
Las aguas de la discordia: la disputa por el Río Colorado (1904-1961)
}

\section{Contentious Waters: The Dispute Over the Colorado River (1904-1961)}

Aidé Grijalva Instituto de Investigaciones Sociales, Universidad Autónoma de Baja California, Mexicali, México. aidel@uabc.edu.mx

Resumen - Desde que en 1848 se firmara el Tratado Guadalupe Hidalgo, mediante el cual México perdió la mitad de su territorio, el Colorado ha sido objeto de un sinfín de pugnas internacionales motivadas por el control de sus aguas. Sus $2.300 \mathrm{~km}$ de longitud lo convierten en la corriente más larga de la costa del Pacífico y en un factor crucial para el suministro de agua en el oeste de los Estados Unidos. De hecho, desde finales del siglo XIX tuvo un rol fundamental en la expansión de la frontera agrícola estadounidense hacia sus límites continentales occidentales. Por tal motivo, y a pesar de que de su inmensa cuenca sólo le corresponde a México un mínimo porcentaje, la parte mexicana fue disputada por empresas y agencias de irrigación de los Estados Unidos, que no dudaron en violar un tratado internacional de límites y aguas para tener el control total de dicha corriente hidráulica y garantizar así la apertura de tierras en el suroeste estadounidense.

Abstract - Since 1848, when the Treaty of Guadal upe Hidal go was signed, resulting in the loss of half of Mexico's national territory, the Colorado River has been the subject of countless international conflicts motivated by competing claims over the control of its waters. At 2,300 kilometers in length, the river is the longest waterway of the Pacific coast and a crucial element of the water supply needs of the western United States. In fact, since the late nineteenth century, the Colorado River played a key role in the expansion of the U.S. agricultural frontier that extends to its western continental confines. Therefore, despite the river's immense basin, Mexico enjoys only a fraction of it. That tiny portion was disputed by U.S. companies and irrigation agencies, which did not hesitate to violate an international treaty of limits and waters in order to gain total control of its hydraulic currents and thereby ensure the opening of commercial lands in the American southwest.

Palabras clave: Irrigación, frontera, río internacional, Baja California, California, México, Estados Unidos Keywords: Irrigation, borderlands, Colorado River, California, Mexico-United States relations

Información Artículo: Recibido: 21 noviembre 2013 Revisado: 17 marzo $2014 \quad$ Aceptado: 3 abril 2014

(c) Universidad de J aén / Seminario Permanente Agua, Territorio y Medio Ambiente (CSIC) 